Article

\title{
Vesiculopolins, a New Class of Anti-Vesiculoviral Compounds, Inhibit Transcription Initiation of Vesiculoviruses
}

\author{
Minako Ogino ${ }^{1}$, Yuriy Fedorov ${ }^{2}$, Drew J. Adams ${ }^{3}$, Kazuma Okada ${ }^{4,}{ }^{\dagger}$, Naoto Ito ${ }^{4,5}$, \\ Makoto Sugiyama ${ }^{4}$ and Tomoaki Ogino ${ }^{1,6, * \mathbb{D}}$ \\ 1 Department of Molecular Biology and Microbiology, Case Western Reserve University School of Medicine, \\ Cleveland, $\mathrm{OH} 44106$, USA \\ 2 Small Molecule Drug Development Core, Case Western Reserve University School of Medicine, Cleveland, \\ $\mathrm{OH} 44106$, USA \\ 3 Department of Genetics and Genome Sciences, Case Western Reserve University School of Medicine, \\ Cleveland, OH 44106, USA \\ 4 Laboratory of Zoonotic Diseases, Faculty of Applied Biological Sciences, Gifu University, 1-1 Yanagido, \\ Gifu 501-1193, Japan \\ 5 Gifu Center for Highly Advanced Integration of Nanosciences and Life Sciences (G-CHAIN), \\ Gifu University, 1-1 Yanagido, Gifu 501-1193, Japan \\ 6 Department of Inflammation and Immunity, Lerner Research Institute, Cleveland Clinic, Cleveland, \\ $\mathrm{OH} 44195$, USA \\ * Correspondence: tomoaki.ogino@case.edu; Tel.: +1-216-368-2070 \\ † Present address: Division of Microbiology, Osaka Institute of Public Health, Osaka 543-0026, Japan.
}

Received: 19 August 2019; Accepted: 11 September 2019; Published: 14 September 2019

\begin{abstract}
Vesicular stomatitis virus (VSV) represents a promising platform for developing oncolytic viruses, as well as vaccines against significant human pathogens. To safely control VSV infection in humans, small-molecule drugs that selectively inhibit VSV infection may be needed. Here, using a cell-based high-throughput screening assay followed by an in vitro transcription assay, compounds with a 7-hydroxy-6-methyl-3,4-dihydroquinolin-2 $(1 \mathrm{H})$-one structure and an aromatic group at position 4 (named vesiculopolins, VPIs) were identified as VSV RNA polymerase inhibitors. The most effective compound, VPI A, inhibited VSV-induced cytopathic effects and in vitro mRNA synthesis with micromolar to submicromolar 50\% inhibitory concentrations. VPI A was found to inhibit terminal de novo initiation rather than elongation for leader RNA synthesis, but not mRNA capping, with the VSV L protein, suggesting that VPI A is targeted to the polymerase domain in the L protein. VPI A inhibited transcription of Chandipura virus, but not of human parainfluenza virus 3, suggesting that it specifically acts on vesiculoviral L proteins. These results suggest that VPIs may serve not only as molecular probes to elucidate the mechanisms of transcription of vesiculoviruses, but also as lead compounds to develop antiviral drugs against vesiculoviruses and other related rhabdoviruses.
\end{abstract}

Keywords: vesicular stomatitis virus; Chandipura virus; vesiculoviruses; L protein; RNA-dependent RNA polymerase; transcription; small molecule inhibitor; oncolytic viruses; vaccine vectors

\section{Introduction}

Vesicular stomatitis virus (VSV, an animal vesiculovirus belonging to the Rhabdoviridae family) has served as a paradigm for studying the molecular mechanisms of transcription and replication by nonsegmented negative strand RNA viruses (e.g., rabies virus (RABV), measles virus, Ebola virus). VSV has now become a clinically important virus that has the potential to be developed as an 
oncolytic virus [1-6] as well as a promising vaccine vector against human pathogens, such as Ebola virus [7-9]. However, safety concerns remain regarding potential side effects (e.g., viraemia, arthritis, conjunctivitis, oral ulcers, dermatitis, vesicle lesions, and encephalitis) caused by possible replication of VSV in peripheral organs [8,10,11] and potentially the brain [12-15]. Although genetic engineering of recombinant live-attenuated VSVs has significantly improved the safety of the VSV therapy [2-4,7], anti-VSV drugs may further decrease the risk of the potential side effects caused by VSV replication after cancer treatment or vaccination. Such drugs may be necessary, if unanticipated dissemination of live-attenuated VSV itself or its pathogenic revertant occurs in cancer patients and, particularly, immunocompromised individuals.

VSV possesses a multifunctional RNA-dependent RNA polymerase (RdRp) L protein, which catalyzes all enzymatic reactions required for transcription and replication (reviewed in [16,17]). During transcription, the VSV L protein complexed with its cofactor P protein synthesizes the leader RNA (LeRNA, 47 nucleotides (nt)) and 5'-capped and 3'-polyadenylated mRNAs from the genome encapsidated with the $\mathrm{N}$ proteins (called N-RNA template) by a stop-start transcription mechanism [18-21]. A GDP polyribonucleotidyltransferase (PRNTase) domain in the L proteins of rhabdoviruses, such as VSV, Chandipura virus (CHPV), and RABV, carries out not only unconventional mRNA capping [22-25], but also transcriptional control [26-29]. Since the RdRp and PRNTase [26], but not methyltransferase [30,31], activities of the L protein are essential for VSV propagation in host cells, the RdRp and PRNTase domains are attractive targets for developing anti-rhabdoviral agents.

In this study, to screen a small-molecule library for anti-VSV compounds, we established a VSV cell killing assay that monitors VSV-induced cytopathic effects (CPEs) by using a cell viability assay with the Cell Counting Kit-8 (CCK-8) reagent [32]. Using the cell killing assay and following in vitro VSV transcription assay, we identified structurally related compounds (named vesiculopolins, VPIs) that inhibit VSV RNA synthesis as well as VSV-induced CPEs. We demonstrated that VPI A (the most effective compound) inhibits transcription initiation, but not mRNA capping, with the RNA-dependent RNA polymerase (RdRp) L protein of VSV. Furthermore, VPI A showed a weak inhibitory activity against transcription by the L protein of CHPV, which is closely related to VSV and associated with acute encephalitis in children with high mortality rate $[33,34]$.

\section{Materials and Methods}

\subsection{Chemicals}

A small-molecule library composed of 50,000 structurally diverse compounds and selected compounds (see Table 1) were acquired from ChemBridge Corporation (San Diego, CA, USA) by the Small Molecule Drug Development Core (Case Western Reserve University). Ribavirin was purchased from Cayman Chemical (Ann Arbor, MI, USA). Nucleotides were obtained from Trilink Biotechnologies (San Diego, CA, USA). [ $\left.\alpha{ }^{3}{ }^{32} \mathrm{P}\right] \mathrm{GTP}$ and $\left[\alpha^{-32} \mathrm{P}\right] \mathrm{CTP}$ were from PerkinElmer (Waltham, MA, USA).

\subsection{Viruses}

Recombinant VSV (wild-type, Indiana) and VSV expressing AcGFP (VSV-AcGFP) were generated from the pVSV-FL2 plasmid [35] and a modified pVSV-FL2 plasmid with an additional AcGFP gene unit (derived from pAcGFP-C1, Takara Bio USA, Mountain View, CA, USA) between the $N$ and $P$ genes, respectively, as described in $[26,36]$. Please note that the full-length VSV genome encoded by the pVSV-FL2 plasmid has been used as a backbone to develop oncolytic virus candidates [2,37-39] as well as vaccine candidates [7,40-42]. VSV and CHPV (653514 strain, VR-476, ATCC, Manassas, VA, USA) were propagated in BHK-21 cells (CCL-10, ATCC). Human parainfluenza virus 3 (HPIV-3, 47855 strain) was propagated in HeLa cells (CCL-2, ATCC). Recombinant RABV strain Nishigahara expressing luciferase (Ni-Luc) was generated as described previously [43]. 


\subsection{VSV Cell Killing Assay in a 384-Well Format}

BHK-21 cells $\left(4 \times 10^{3}\right.$ cells, $20 \mu$ L Dulbecco's Modified Eagle's Medium (DMEM, Thermo Fisher Scientific, Waltham, MA, USA) supplemented with $7.5 \%$ heat-inactivated fetal bovine serum (FBS, Thermo Fisher Scientific)) were seeded in each well of transparent 384-well plates using a MultiFlo FX multi-mode reagent dispenser (BioTek, Winooski, VT, USA). Using a JANUS automated liquid handling workstation with a 384-pin tool (PerkinElmer), $50 \mathrm{~nL}$ of each small-molecule compound $(10 \mathrm{mM}$, dissolved in dimethyl sulfoxide (DMSO)) or DMSO was added to each well of the plates. Using the BioTek dispenser, $10 \mu \mathrm{L}$ of a VSV dilution in DMEM $\left(4 \times 10^{4}\right.$ plaque-forming units $\left./ \mathrm{mL}\right)$ was added to each well to infect the cells at a multiplicity of infection (MOI) of 0.1. Control wells for mock-infection received $10 \mu \mathrm{L}$ of DMEM culture medium. The plates were agitated using a microplate mixer. The final concentrations of the compounds and DMSO were $\sim 17 \mu \mathrm{M}$ and $\sim 0.17 \%$, respectively. The cells were incubated at $37^{\circ} \mathrm{C}$ in a $\mathrm{CO}_{2}$ incubator. At $24 \mathrm{~h}$ post-infection, $10 \mu \mathrm{L}$ of $2 \% \mathrm{CCK}-8$ (Dojindo Molecular Technologies, Rockville, MD, USA) diluted in DMEM was added to each well. After incubation of the cells for $1.5-2 \mathrm{~h}$ at $37^{\circ} \mathrm{C}$ in the $\mathrm{CO}_{2}$ incubator, the absorbance at $450 \mathrm{~nm}\left(\mathrm{~A}_{450}\right)$ was measured using an EnSpire multimode plate reader (PerkinElmer). Mean $(\mu)$ and standard deviation $(\delta)$ values for $\mathrm{A}_{450}$ of mock $(\mathrm{m})$ - and VSV (v)-infected cell control wells $(n=32)$ were determined for 157 plates. The $Z^{\prime}$ factor $[44,45]$ for each plate was calculated using the formula: $1-\left(3 \delta_{\mathrm{m}}+3 \delta_{\mathrm{v}}\right) /\left(\mu_{\mathrm{m}}-\mu_{\mathrm{v}}\right)$. The percent inhibition of VSV-induced metabolic shut-down was calculated using the following formula: $100 \times$ $\left(\mathrm{A}_{450}\right.$ of each sample well $\left.-\mu_{\mathrm{v}}\right) /\left(\mu_{\mathrm{m}}-\mu_{\mathrm{v}}\right)$. After measuring the absorbance, the cells were fixed by adding $5 \mu \mathrm{L}$ of $37 \%$ formaldehyde containing $40 \mu \mathrm{g} / \mathrm{mL}$ Hoechst 33342 dye (Sigma-Aldrich, St. Louis, MO, USA) [46]. VSV-induced nuclear condensation was analyzed using an Operetta high-content imaging system with a 20× objective (PerkinElmer) according to the manufacturer's instructions for an apoptosis cell imaging assay (PerkinElmer). Image analyses and calculations were performed using Acapella and Harmony 4.1 software packages (PerkinElmer). Compounds displaying $30 \%$ or more inhibition of VSV-induced metabolic shut-down and nuclear condensation were selected as hits. Cells in hit wells were also observed under a microscope to confirm inhibition of VSV-induced cell rounding.

\subsection{VSV Cell Killing Assay in a 96-Well Format}

BHK-21 cells $\left(2.5 \times 10^{4}\right.$ cells, $50 \mu \mathrm{L}$ DMEM supplemented with $10 \%$ FBS $)$ were seeded in each well of transparent 96 -well plates. After the addition of $25 \mu \mathrm{L}$ of each small molecule $(0.78-400 \mu \mathrm{M}, 0.8 \%$ DMSO) in DMEM or $0.8 \%$ DMSO in DMEM to each well of the plates, $25 \mu \mathrm{L}$ of a virus dilution (VSV or CHPV) in DMEM $\left(1 \times 10^{5}\right.$ plaque-forming units $\left./ \mathrm{mL}\right)$ was added to each well to infect the cells at an MOI of 0.1. Control wells for mock-infection received $25 \mu \mathrm{L}$ of DMEM culture medium. The final concentrations of each small molecule and DMSO were $0.2-100 \mu \mathrm{M}$ and $0.2 \%$, respectively. The cells were incubated at $37^{\circ} \mathrm{C}$ in a $\mathrm{CO}_{2}$ incubator. At $24 \mathrm{~h}$ post-infection, $10 \mu \mathrm{L}$ of CCK-8 was added to each well. After incubation of the cells for $1.5-2 \mathrm{~h}$ at $37^{\circ} \mathrm{C}$, the absorbance at $\mathrm{A}_{450}$ was measured using the Thermo Multiskan FC microplate photometer (Thermo Fisher Scientific). The percent inhibition of VSV-induced metabolic shut-down by various concentrations of small molecules was calculated as described in Section 2.3. Fifty percent inhibitory concentration $\left(\mathrm{IC}_{50}\right)$ values were determined by fitting experimental data to the four-parameter logistic equation using Graphpad Prism software (version 7) (GraphPad Software, San Diego, CA, USA). The percent cell viability was calculated using the following formula: $100 \times\left(\mathrm{A}_{450}\right.$ of each sample well $-\mathrm{A}_{450}$ of a well without cells (blank)) / ( $\mu_{\mathrm{m}}$ - blank). Similarly, HeLa cells $\left(2.5 \times 10^{4}\right.$ cells) were infected with VSV at an MOI of 0.1 in the presence or absence of various concentrations of each small molecule in a 96-well plate, and cultured for $65 \mathrm{~h}$. The cell viability was determined as described above, except that the cells were incubated with CCK8 for 40-60 min.

\subsection{Other VSV Cell Infection Assays}

BHK-21 cells $\left(2.5 \times 10^{4}\right.$ cells) were infected with VSV at an MOI of 0.1 in the presence of various concentrations of each small molecule in a 96-well plate and incubated for $24 \mathrm{~h}$ as described in 
Section 2.4. The culture supernatants were subjected to a plaque assay to determine their virus titers [26]. Similarly, BHK-21 cells were infected with VSV-AcGFP and cultured for $24 \mathrm{~h}$. After addition of Hoechst 33342 to culture medium to a final concentration of $5 \mu \mathrm{g} / \mathrm{mL}$, cells were incubated for $30 \mathrm{~min}$ at $37^{\circ} \mathrm{C}$ in a $\mathrm{CO}_{2}$ incubator, and then observed under a fluorescent microscope with a $20 \times$ objective (EVOS FLoid Cell Imaging Station, Thermo Fisher Scientific).

\subsection{Preparation of Viral RNPs and Proteins}

The VSV RNP, N-RNA template, and recombinant L and P proteins were prepared as described previously $[22,23,47]$. CHPV was propagated in BHK-21 cells and purified by equilibrium banding on a potassium tartrate-glycerol gradient essentially as described in [48]. CHPV RNP was purified from detergent-disrupted virus particles as described for VSV [22].

HeLa cells were infected with HPIV-3 at an MOI of 5, and cultured for $24 \mathrm{~h}$. The infected cells were homogenized in the hypotonic buffer [49], and a post-nuclear supernatant was prepared from the cell homogenate and subjected to subcellular fractionation as described previously [49]. A microsome (P100) fraction (7.2 mg of protein) was incubated in $5 \mathrm{~mL}$ of a lysis buffer $20 \mathrm{mM}$ Tris- $\mathrm{HCl}(\mathrm{pH} \mathrm{8.0),}$ $100 \mathrm{mM} \mathrm{NaCl}, 1 \mathrm{mM} \mathrm{MgCl} 2,1 \mathrm{mM}$ DTT, $2 \%$ Triton X-100) for $15 \mathrm{~min}$ at $4{ }^{\circ} \mathrm{C}$, and centrifuged at $15,000 \times g$ for $10 \mathrm{~min}$. The resulting pellet containing HPIV-3 RNP was suspended in the isotonic buffer [49] to obtain a crude RNP fraction (2.8 $\mathrm{mg}$ protein/mL, $1 \mathrm{~mL})$.

\subsection{In Vitro Transcription and Capping Assays}

In vitro transcription was performed with $0.2 \mu \mathrm{g}$ protein of VSV or CHPV RNP in the presence of $0.1 \mathrm{mM}\left[\alpha^{-32} \mathrm{P}\right] \mathrm{GTP}$ and $1 \mathrm{mM}$ each of ATP, CTP, and UTP as detailed previously [47]. For HPIV-3, $3.5 \mu \mathrm{g}$ protein of the crude RNP fraction was used for in vitro transcription. In vitro AC synthesis (first phosphodiester bond formation) was carried out with $2 \mathrm{mM}$ ATP and $20 \mu \mathrm{M}\left[\alpha_{-}{ }^{32} \mathrm{P}\right] \mathrm{CTP}$ as described in [28]. In vitro oligo-RNA capping was conducted with $0.25 \mu \mathrm{M}\left[\alpha^{-32} \mathrm{P}\right] \mathrm{GDP}, 2.5 \mu \mathrm{M}$ pppAACAG, and $60 \mathrm{ng}$ of the recombinant L protein as described previously [50]. The above enzymatic reactions were performed in the presence of different concentrations of VPI A. All the reaction mixtures included $2 \%$ DMSO. ${ }^{32}$ P-Labeled RNA products were analyzed by electrophoresis in 5\% (for mRNAs) or $20 \%$ (for LeRNA, ApC, and capped oligo-RNA) polyacrylamide gels containing 7 M urea (urea-PAGE) followed by autoradiography $[47,50]$. Statistical analyses were performed by one-way ANOVA using the Graphpad Prism software.

\subsection{In Vitro Pulse-Chase Lerna Synthesis Assay}

The recombinant $\mathrm{L}(0.15 \mu \mathrm{g})$ and $\mathrm{P}(0.05 \mu \mathrm{g})$ proteins were preincubated with $\mathrm{N}-\mathrm{RNA}(0.4 \mu \mathrm{g}$ protein) in the presence or absence of VPI A (final concentration: 1 or $10 \mu \mathrm{M}$ ) in $23 \mu \mathrm{L}$ of the transcription buffer [47] without NTPs at $30{ }^{\circ} \mathrm{C}$ for $30 \mathrm{sec}$. After the addition of $2 \mu \mathrm{L}$ of a mixture containing ATP, CTP (final concentration: $1 \mathrm{mM}$ each), and [ $\left.\alpha{ }^{32} \mathrm{P}\right] \mathrm{GTP}$ (final concentration: $1 \mu \mathrm{M}, \sim 400 \mathrm{cpm} / \mathrm{fmol}$ ), the reaction mixtures were incubated at $30{ }^{\circ} \mathrm{C}$ for $3 \mathrm{~min}$ (pulse). The reactions were terminated by the addition of the RNA extraction buffer [47]. RNA products including LeRNA with residues 1-18 (LeRNA $1-18$ ) were extracted, precipitated, and then analyzed by 20\% urea-PAGE followed by autoradiography as described previously [47].

To analyze effects of VPI A on elongation of LeRNA $1-18$ to LeRNA (47 nt), ${ }^{32}$ P-labeled LeRNA $1-18$ was synthesized without any inhibitors as described above ( $p u l s e)$. After adding $5 \mu \mathrm{L}$ of the transcription buffer containing GTP and UTP (final concentration: $1 \mathrm{mM}$ each) with or without VPI A (final concentration: 1 or $10 \mu \mathrm{M}$ ) to the reaction mixtures, the reactions were continued for additional $1 \mathrm{~min}$ at $30{ }^{\circ} \mathrm{C}$ (chase) and then terminated. RNA products were analyzed as described above.

An oligo-DNA (5'-AATGGTTTGTTTGTCTTCGTTATAGTGAGTCGTATTA, template region underlined) was annealed to $5^{\prime}$-TAATACGACTCACTAT (class III T7 promoter sequence) and used as a template to synthesize a LeRNA $1-18$ marker with ATP, CTP, and [ $\alpha{ }^{32}$ P]GTP by T7 RNA polymerase as described before [47,51]. 


\section{Results}

\subsection{Discovery of Vesiculopolins as VSV RdRp Inhibitors}

To find small molecules that rescue cultured BHK-21 cells (hamster kidney fibroblast cells) from VSV-induced CPEs (e.g., metabolic shut-down, nuclear condensation, cell rounding), we performed screening of the ChemBridge library composed of 50,000 drug-like molecules (final concentration: $\sim 17 \mu \mathrm{M}$ ) by using the VSV cell killing assay in a 384-well format (Figure 1A). In this assay, VSV-induced metabolic shut-down was measured as a decrease in cellular dehydrogenase activities with the colorimetric CCK-8 reagent containing a water-soluble tetrazolium salt and electron mediator [32]. To evaluate the assay quality for every assay plate, we determined the $Z^{\prime}$ factor $[44,45]$ based on the absorbance of mockand VSV-infected cell control wells (Figure 1B). The overall $Z^{\prime}$ factor was $0.75 \pm 0.06$ (mean \pm standard deviation, $n=157$ ), indicating that excellent assay conditions were maintained throughout the screen. We identified 13 hit compounds with $\geq 30 \%$ inhibitory activities against VSV-induced metabolic shut-down. Although this screening system based on the rescue of cells from lytic VSV infection might eliminate compounds that are highly toxic to cells from primary hits, we further eliminated compounds that cannot repress VSV-induced apoptotic nuclear condensation by performing a cell imaging assay with the PerkinElmer Operetta. The result showed that 9 compounds ( $0.02 \%$ hit rate) exhibited $\geq 30 \%$ inhibitory activities against VSV-induced nuclear condensation (Table 1).

Using our in vitro transcription system, we revealed that the top 2 compounds (Table 1; Figure 1C, lanes 3 and 4) strongly inhibit VSV mRNA synthesis at $20 \mu \mathrm{M}$, while other 6 compounds moderately or weakly repress mRNA synthesis (lanes 5-9 and 11). These 8 compounds were found to possess a common chemical structure, 7-hydroxy-6-methyl-3,4-dihydroquinolin-2(1H)-one, with an aromatic group at position 4 (Figure 1D). We named these compounds vesiculopolins (VPIs) A-H. Interestingly, VPI F exhibited a weak inhibitory effect on mRNA synthesis, but induced production of larger amounts of unknown transcripts with 2-3 kilo nt (Figure 1C, lane 8, marked by an asterisk) than in the absence of the compound (lane 2). There was only one hit compound, which was structurally unrelated to VPIs and had only a subtle or no effect on mRNA synthesis (Figure 1C, lane 10).

Table 1. Results of primary screening for anti-VSV compounds.

\begin{tabular}{cccccc}
\hline & & & \multicolumn{3}{c}{ \% Inhibition } \\
\cline { 3 - 5 } & ChemBridge ID \# & VPI & $\begin{array}{c}\text { Metabolic } \\
\text { Shut-down } \\
\text { (CCK Assay) }\end{array}$ & $\begin{array}{c}\text { Nuclear } \\
\text { Condensation } \\
\text { (Cell Imaging) }\end{array}$ & $\begin{array}{c}\text { mRNA Synthesis } \mathbf{~}^{2} \\
\text { (In vitro } \\
\text { Transcription) }\end{array}$ \\
\hline 1 & 53425003 & $\mathrm{~A}$ & 105 & 98 & 99 \\
2 & 20208871 & $\mathrm{~B}$ & 102 & 92 & 89 \\
3 & 66896553 & $\mathrm{C}$ & 58 & 63 & 72 \\
4 & 35540582 & $\mathrm{D}$ & 55 & 57 & 72 \\
5 & 80285323 & $\mathrm{E}$ & 50 & 94 & 72 \\
6 & 10443614 & $\mathrm{~F}$ & 48 & 69 & 34 \\
7 & 37324373 & $\mathrm{G}$ & 46 & 54 & 68 \\
8 & 52194062 & & 44 & 51 & 10 \\
9 & 69805228 & & 39 & 10 & n.d. \\
10 & 43534388 & & 35 & 53 & n.d. \\
11 & 90353655 & $\mathrm{H}$ & 34 & 0 & 73 \\
12 & 81699442 & & 31 & 9 & n.d. \\
13 & 66349773 & & 30 & n.d. \\
\hline
\end{tabular}

${ }^{1}$ Compound concentration: $\sim 17 \mu \mathrm{M} ;{ }^{2}$ Compound concentration: $20 \mu \mathrm{M}$; n.d.: not determined. 

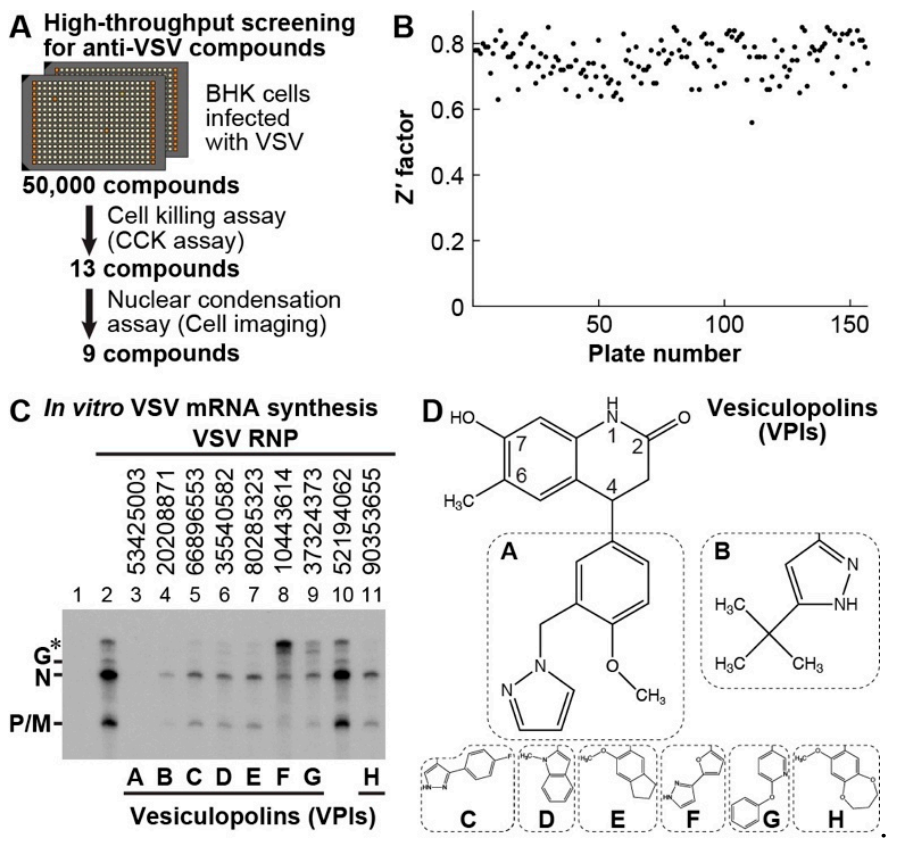

Figure 1. Screening for anti-VSV compounds. A flow diagram of screening for anti-VSV compounds is shown in (A). High-throughput screening of the ChemBridge library composed of 50,000 small molecules was performed for compounds that rescue cells from VSV-induced CPEs (metabolic shut-down and nuclear condensation). BHK-21 cells were mock-infected or infected with VSV at an MOI of 0.1 in the presence or absence of each compound $(\sim 17 \mu \mathrm{M})$ and cultured for $24 \mathrm{~h}$. VSV-induced metabolic shut-down was measured as a decrease in cellular dehydrogenase activities by a colorimetric cell viability assay with the CCK-8 reagent (CCK assay). As described in Section 2.3, the $Z^{\prime}$ factor for each plate was calculated (B). After fixing and staining the cells, cell nuclei were analyzed by an automated cell imaging system. Compounds displaying $\geq 30 \%$ inhibition of VSV-induced metabolic shut-down and nuclear condensation were selected as primary hits. In vitro mRNA synthesis was performed with VSV RNP in the presence or absence of the hit compounds $(20 \mu \mathrm{M})(\mathbf{C})$. Deadenylated mRNAs were analyzed by $5 \%$ urea-PAGE followed by autoradiography. Lane 1 indicates no RNP. Eight-digit ChemBridge identification numbers for the hit compounds are shown above the lanes. The positions of the VSV mRNAs (N, P/M, and G) are indicated. Unknown transcripts of 2-3 kilo nt in length are marked by an asterisk. Eight structurally related compounds (named vesiculopolins, VPI A-H) were identified as VSV RdRp inhibitors. VPIs have a common structure [7-hydroxy-6-methyl-3,4-dihydroquinolin-2(1H)-one] with a variable group at position 4 (D). The chemical structure of VPI A is shown as a representative. For VPIs B-H, only substituent groups at position 4 are shown.

\subsection{Antiviral Activities of Vesiculopolins A and B against Rhabdoviruses}

We further characterized VPIs A and B, because they showed more potent inhibitory activities against in vitro mRNA synthesis as well as VSV-induced CPEs among VPIs (Figure 1C and Table 1). VPIs A and B inhibited VSV-induced metabolic shut-down, with $\mathrm{IC}_{50}$ values of 2 and $6 \mu \mathrm{M}$, respectively (Figure 2A, Table 2), and have little or no cytotoxic effects on BHK-21 cells at a concentration of $100 \mu \mathrm{M}$ (Figure 2B). In contrast, ribavirin, a broad-spectrum antiviral drug, exhibited significant cytotoxic effects $\left(\mathrm{CC}_{50}: 86 \mu \mathrm{M}\right)$ on BHK-21 cells (Figure 2B and Table 2), rather than anti-VSV effects (Figure 2A), at concentrations ranging from 25 to $100 \mu \mathrm{M}$.

VPIs A and B almost completely abolished VSV production from BHK-21 cells at concentrations of $\geq 12.5$ and $\geq 25 \mu \mathrm{M}$, respectively (Figure $2 \mathrm{C}$ ). Consistently, microscopic observations revealed that VPIs A and B repress VSV-induced cell rounding and detachment in a concentration-dependent manner, and nearly completely protected cells from these CPEs at concentrations of $\geq 12.5$ and $\geq 25 \mu \mathrm{M}$, respectively (Figure 2D). We also confirmed that VPIs A and B abrogate nuclear condensation and AcGFP expression in 
BHK-21 cells infected with VSV with the AcGFP gene at $10 \mu \mathrm{M}$ (Figure 3). Time-of-addition experiments revealed that VPI A inhibits VSV infection at an early post-entry step (Figure S1).
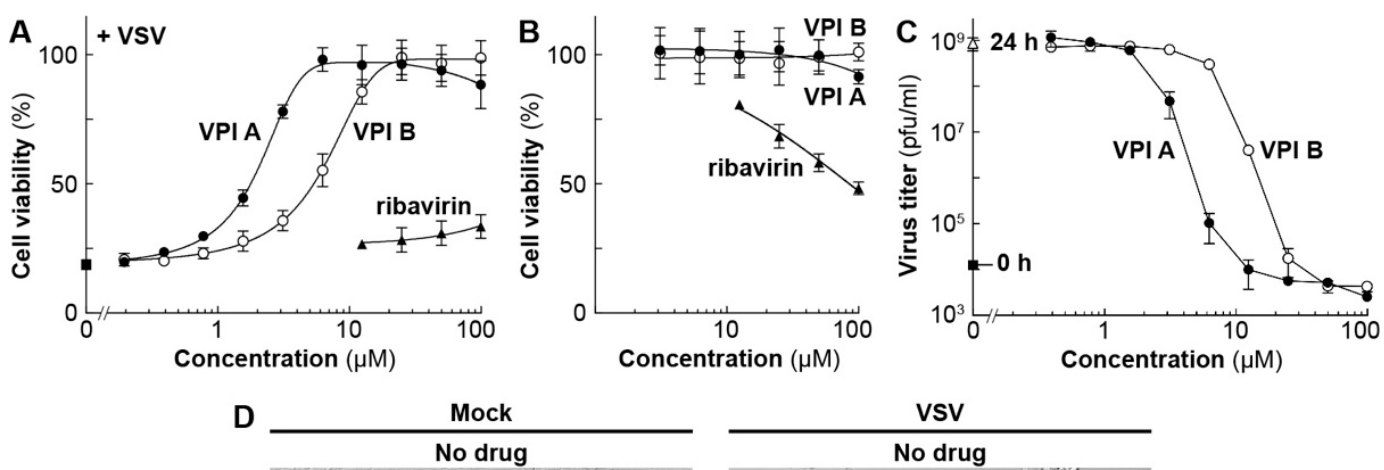

Mock

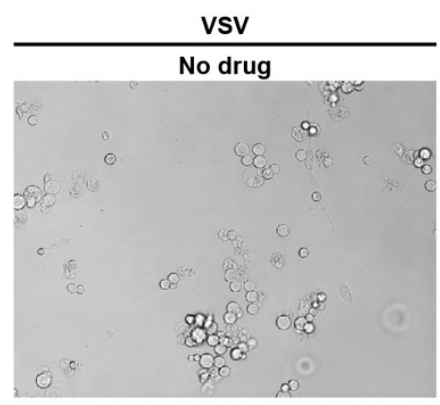

$100 \mu \mathrm{m}$

VSV + VPI A $(\mu \mathrm{M})$

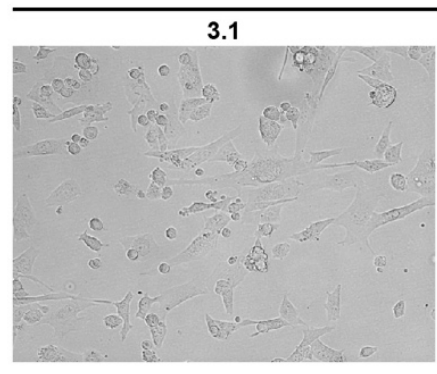

6.3

12.5
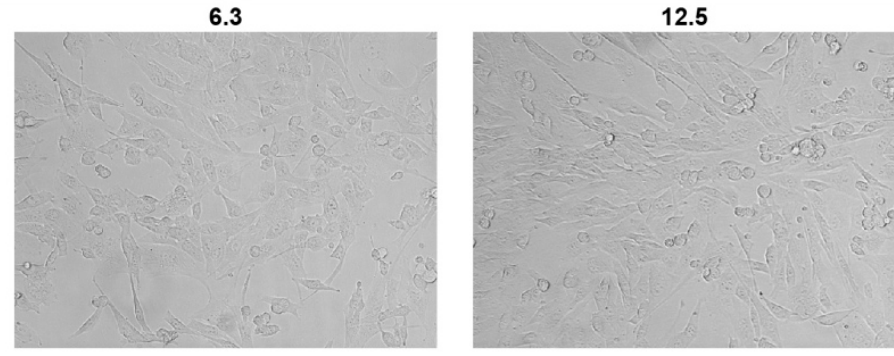

VSV + VPI B $(\mu \mathrm{M})$

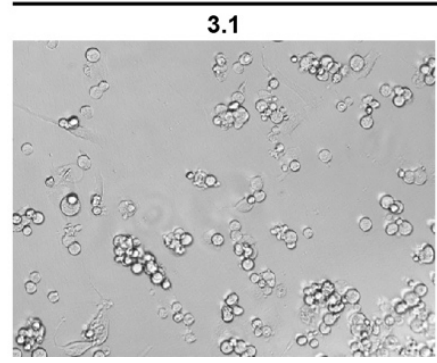

6.3

12.5
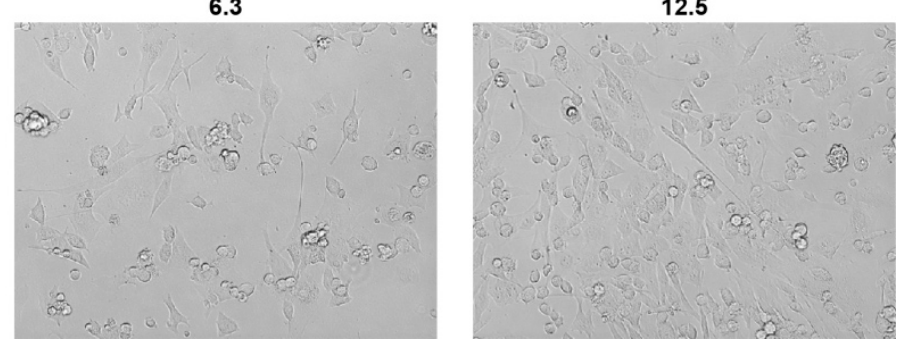

Figure 2. Anti-VSV activities of VPIs A and B in BHK-21 cells. BHK-21 cells in 96-well plates were mock-infected or infected with VSV at an MOI of 0.1 in the presence or absence of different concentrations of VPI A (closed circles), VPI B (open circles), or ribavirin (closed triangles), and cultured for $24 \mathrm{~h}$. The viability of infected (A) or mock-infected (B) cells was assessed by the CCK assay. The viability of mock-infected cells (no drug) was set to $100 \%$. Symbols and error bars represent the means and standard deviations, respectively, of three independent experiments, which were conducted in triplicate. In (A), the viability of infected cells (no drug) is shown by a closed square. VSV titers (plaque-forming units (pfu)/mL) of culture supernatants at $24 \mathrm{~h}$ post-infection were determined by a plaque assay (C). Symbols and error bars indicate the means and standard deviations, respectively, of three experiments. VSV titers of culture supernatants at $0 \mathrm{~h}$ and $24 \mathrm{~h}$ post-infection (no drug) are shown by a closed square and open triangle, respectively. The mock-infected or infected cells in the presence or absence of VPI A or B at various concentrations were observed under a microscope (D). 
Table 2. Anti-vesiculoviral activities of VPI A, VPI B, and ribavirin.

\begin{tabular}{|c|c|c|c|c|c|c|c|c|}
\hline \multirow[t]{3}{*}{ Compound } & \multicolumn{5}{|c|}{ BHK-21 Cells } & \multicolumn{3}{|c|}{ HeLa Cells } \\
\hline & \multirow{2}{*}{$\begin{array}{c}\text { Cytotoxicity } \\
\text { CC }_{50}{ }^{1}\end{array}$} & \multicolumn{2}{|c|}{ Anti-VSV Activity } & \multicolumn{2}{|c|}{ Anti-CHPV Activity } & \multirow{2}{*}{$\begin{array}{c}\text { Cytotoxicity } \\
\mathrm{CC}_{50}{ }^{1}\end{array}$} & \multicolumn{2}{|c|}{ Anti-VSV Activity } \\
\hline & & $\mathrm{IC}_{50}{ }^{1}$ & $\mathrm{SI}^{2}$ & $\mathrm{IC}_{50}{ }^{1}$ & $\mathrm{SI}^{2}$ & & $\mathrm{IC}_{50}{ }^{1}$ & $\mathrm{SI}^{2}$ \\
\hline VPI A & $>100$ & $2.0 \pm 0.1$ & $>50$ & $7.9 \pm 0.4$ & $>13$ & $>100$ & $0.42 \pm 0.02$ & $>240$ \\
\hline VPI B & $>100$ & $6.2 \pm 0.2$ & $>16$ & $11 \pm 1$ & $>9$ & $>100$ & $1.1 \pm 0.1$ & $>91$ \\
\hline Ribavirin & $86 \pm 0.5$ & $>100$ & $<1$ & $>100$ & $<1$ & $>100$ & $15 \pm 1$ & $>7$ \\
\hline
\end{tabular}

${ }^{1}$ Values $(\mu \mathrm{M})$ represent means \pm standard errors of the means $(n=9) .{ }^{2}$ Selectivity index (SI) was calculated by dividing the $\mathrm{CC}_{50}$ values by the $\mathrm{IC}_{50}$ values.
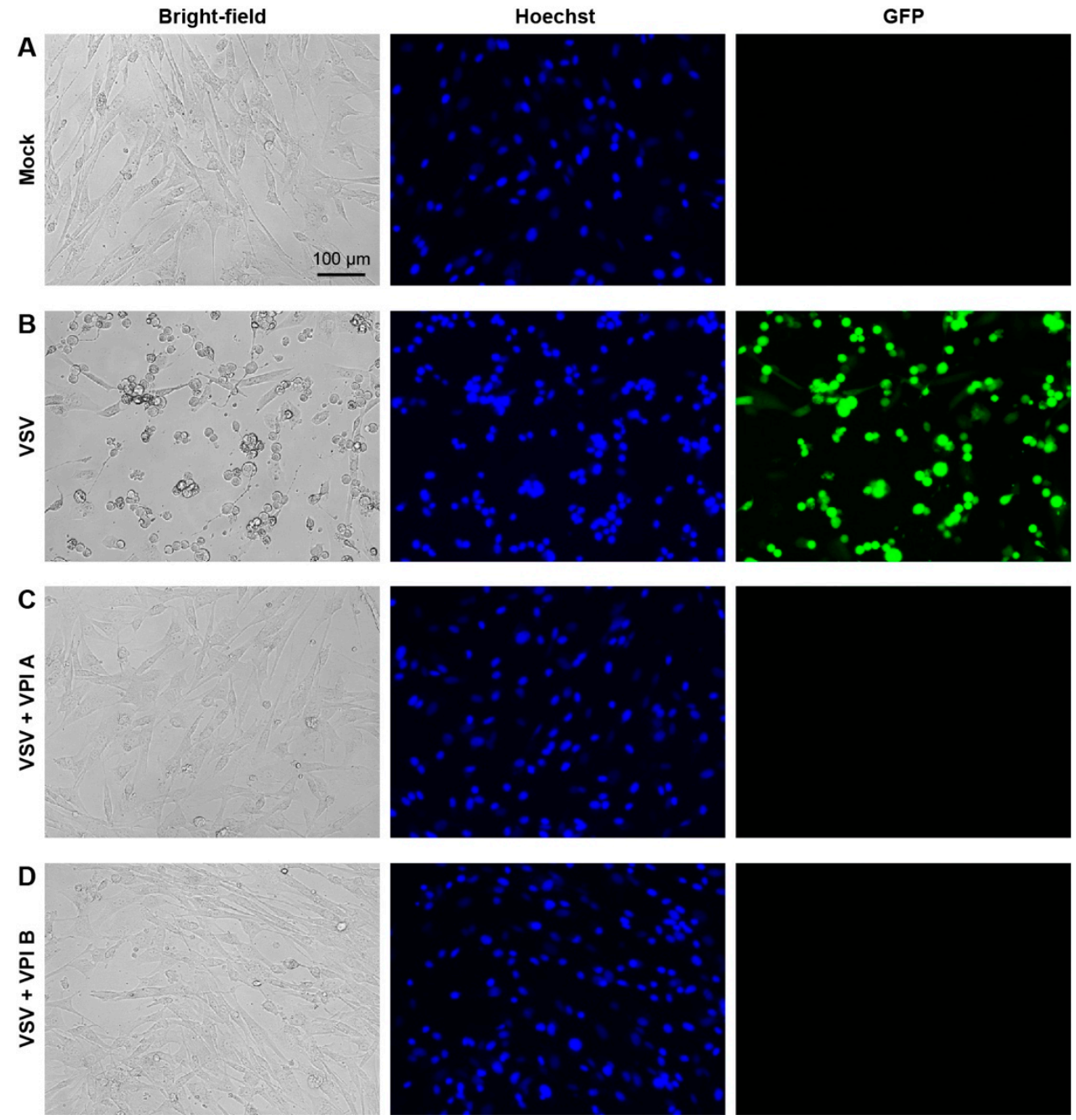

Figure 3. VPIs A and B inhibit VSV-induced CPEs and gene expression. BHK-21 cells were mock-infected (A) or infected with recombinant VSV expressing AcGFP at an MOI of 0.1 (B-D) in the presence or absence (A,B) of $10 \mu \mathrm{M}$ VPI A (C) or B (D). At $24 \mathrm{~h}$ post-infection, cells were stained with Hoechst 33342 , and observed under a fluorescent microscope.

VPIs A and B also inhibited VSV-induced metabolic shut-down in HeLa cells (human cervical cancer cells) with $\mathrm{IC}_{50}$ values of 0.4 and $1 \mu \mathrm{M}$, respectively (Figure $4 \mathrm{~A}$, Table 2 ) and cell rounding and detachment at $2.5 \mu \mathrm{M}$ (Figure 4C), and were less toxic to the HeLa cells at $100 \mu \mathrm{M}$ during the $65 \mathrm{~h}$ incubation period (Figure 4B). On the other hand, ribavirin protected HeLa cells from VSV infection at high concentrations $\left(\mathrm{IC}_{50}: 15 \mu \mathrm{M}\right.$ ) without significant cytotoxicity (Figure $4 \mathrm{~A}-\mathrm{C}$ ), consistent with the reported cell-type-specific anti-VSV effects of ribavirin [52]. 


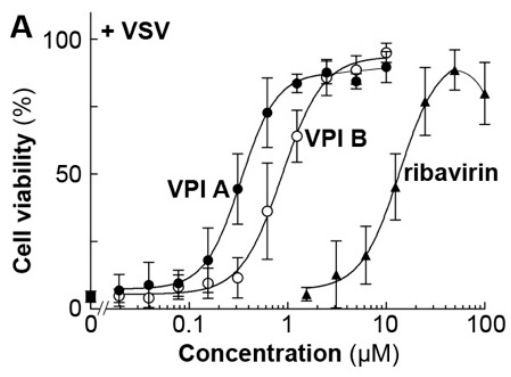

C

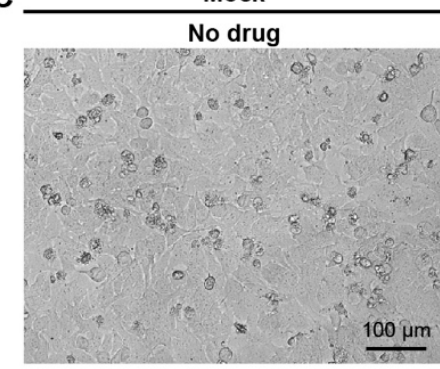

$100 \mu \mathrm{m}$
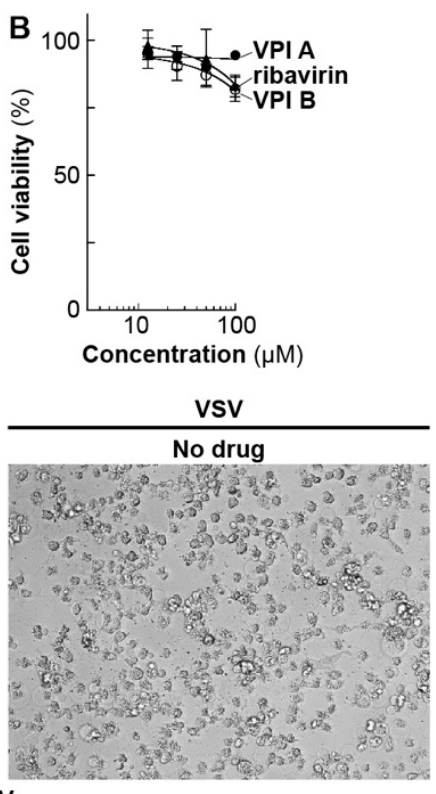

VSV
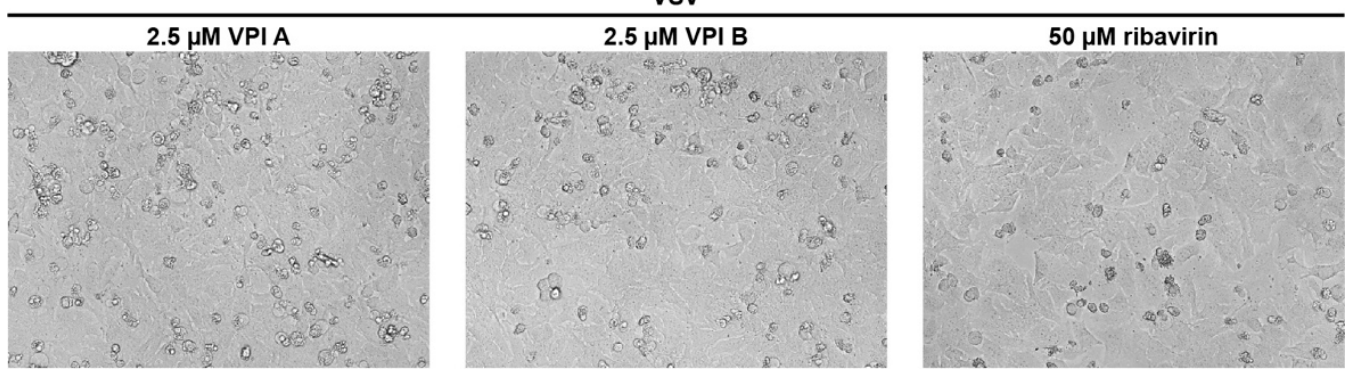

Figure 4. Anti-VSV activities of VPIs A and B in HeLa cells. HeLa cells in 96-well plates were mock-infected or infected with VSV at an MOI of 0.1 in the presence of different concentrations of VPI A (closed circles), VPI B (open circles), or ribavirin (closed triangles), and cultured for $65 \mathrm{~h}$. The cell viability of infected (A) or mock-infected (B) cells was determined as described in Figure 2. The mock-infected or infected cells in the presence or absence of the indicated compounds were observed under a microscope (C).

We analyzed antiviral activities of VPIs A and B against other rhabdoviruses. VPIs A and $\mathrm{B}$ inhibited CHPV-induced CPEs, such as metabolic shut-down ( $\mathrm{IC}_{50}: 8$ and $11 \mu \mathrm{M}$, respectively) (Figure 5A, Table 2) and cell rounding and detachment (Figure 5B), although to lesser extents. VPI A also exhibited a weak inhibitory effect on RABV gene expression in infected mouse neuroblastoma NA cells $\left(\mathrm{IC}_{50}: 26 \mu \mathrm{M}\right)$ when using the cell infection assay with recombinant RABV expressing firefly luciferase [43] (Figure S2 and Table S1). In contrast, VPI B showed little or no inhibitory effect on RABV gene expression, even at $100 \mu \mathrm{M}$. Although these results cannot be directly compared, the antiviral effects of VPIs against RABV seem to be remarkably weaker than those against vesiculoviruses. On the other hand, neither of the compounds showed any antiviral effects against HPIV-3, a paramyxovirus, when using a cell killing assay for HeLa cells (Figure S3 and Table S2). 

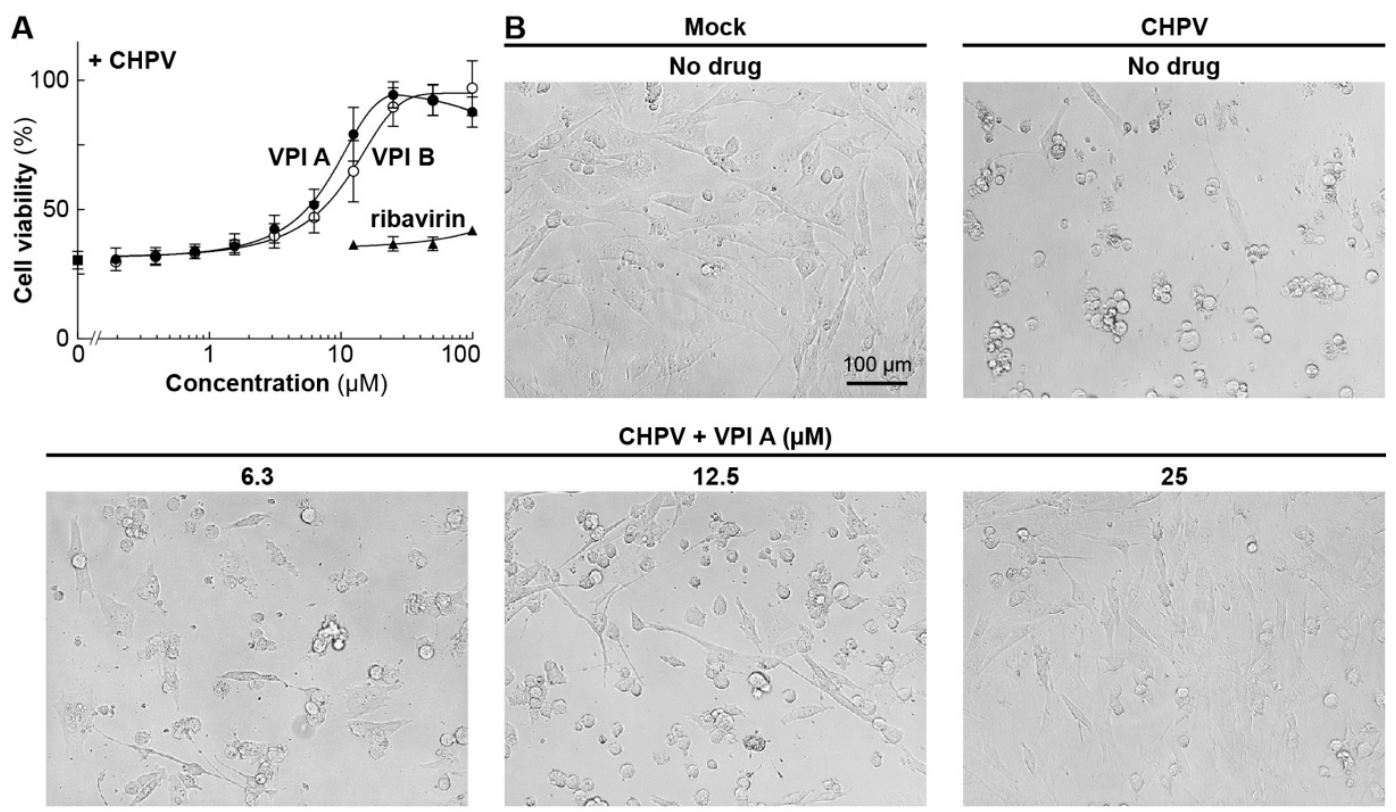

$\mathrm{CHPV}+\mathrm{VPI} A(\mu \mathrm{M})$

12.5
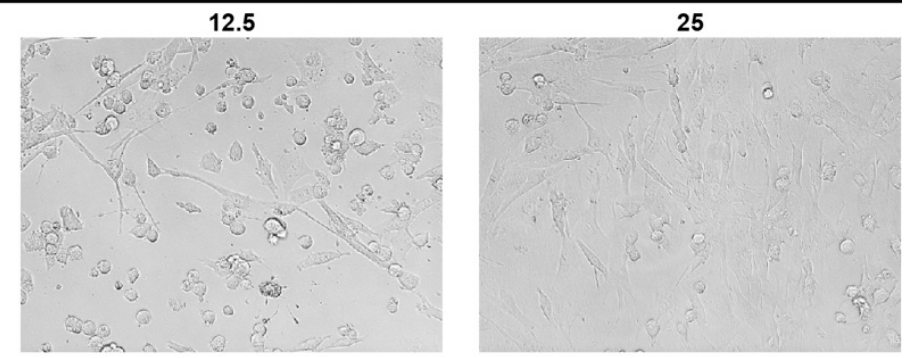

$\mathrm{CHPV}+\mathrm{VPI} \mathrm{B}(\mu \mathrm{M})$

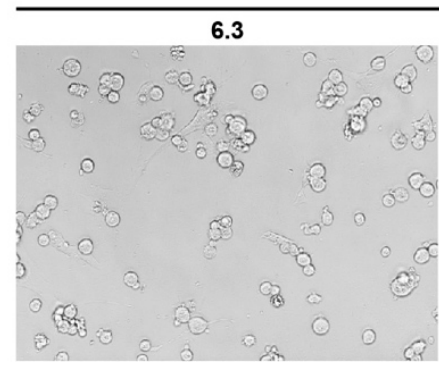

12.5
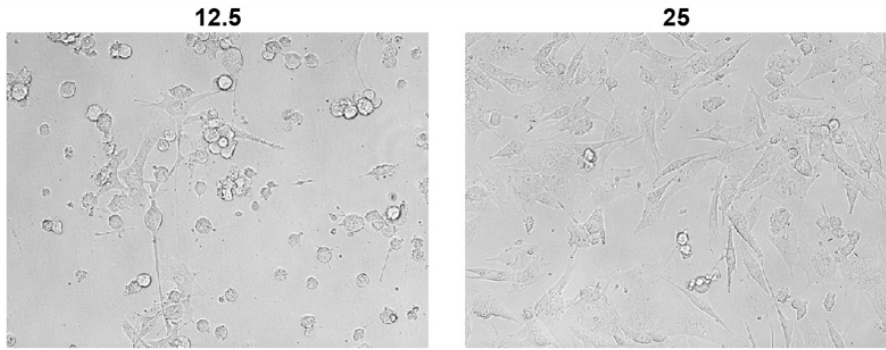

Figure 5. Anti-CHPV activities of VPIs A and B in BHK-21 cells. The viability of CHPV-infected BHK cells in the presence of different concentrations of VPI A, VPI B or ribavirin was determined by the CCK assay (A) as described in Figure 2. Indicated cells were observed under a microscope (B).

\subsection{The Mode of Action of Vesiculopolin A in Inhibition of VSV RdRp}

To investigate the mode of action of VPIs, we used VPI A, the most potent anti-VSV compound among them. Consistent with the antiviral effects of VPI A, it inhibited in vitro mRNA synthesis of VSV (Figure $6 \mathrm{~A}$ ) and CHPV (Figure 6B), but not of HPIV-3 at $10 \mu \mathrm{M}$ (Figure $6 \mathrm{C}$ ). IC $_{50}$ values against VSV and CHPV mRNA synthesis were calculated to be $0.81 \pm 0.04$ and $3.3 \pm 0.4 \mu \mathrm{M}$ (means \pm standard errors, $n=3$ ), respectively (Figure 6D). According to the single-entry, stop-start transcription model [19-21,53], the VSV RdRp complex initiates RNA synthesis at the 3 '-end of the genome to sequentially synthesize LeRNA and mRNAs by following the gene order: Le-N-P-M-G-L (Figure 7A). We found that VPI A represses LeRNA synthesis (Figure 7B), as well as mRNA synthesis (Figure 7C), therefore suggesting that inhibition of LeRNA synthesis may cause the reduction in mRNA synthesis from the internal genes in an indirect manner.

To further investigate the effects of VPI A on different stages of LeRNA synthesis, we established a pulse-chase LeRNA synthesis assay. In this assay, an RdRp complex was preassembled with the recombinant $\mathrm{L}$ and $\mathrm{P}$ proteins on the N-RNA template (Figure $8 \mathrm{~A}$ ). By incubating the complex with ATP, CTP, and $\left[\alpha^{-}{ }^{32} \mathrm{P}\right] \mathrm{GTP}$ ( $p u l s e$ ), the reconstituted RdRp complex was expected to initiate terminal de novo initiation for LeRNA synthesis and subsequently to elongate nascent LeRNA. Then, the RdRp was anticipated to pause at position 18 due to a lack of UTP, which serves as an incoming nucleotide complementary to the A residue at position 19 of the genome. If the RdRp formed a stable elongation complex, ${ }^{32}$ P-labeled LeRNA with residues 1-18 (LeRNA $\left.1-18\right)$ would be elongated to full-length LeRNA (47 nt) by the addition of excess concentrations of GTP and UTP (chase). As expected, during the 
pulse period, the reconstituted RdRp complex produced ${ }^{32} \mathrm{P}$-labeled LeRNA ${ }_{1-18}$, but also synthesized transcripts longer than expected (19-21 nt) (Figure 8B,C, lane 1). Since T7 RNA polymerase was able to terminate transcription at position 18 on the DNA template (see Section 2.8.) without UTP to produce LeRNA $_{1-18}$ (Figure 8B, lane M1), ATP, CTP, and GTP used for transcription seemed to be UTP free. Therefore, these observations suggest two possibilities: the VSV RdRp incorporated UMP from a trace amount of UTP co-purified with the viral proteins or misincorporated AMP, CMP, or GMP into the $3^{\prime}$-end of LeRNA $1-18$. Nevertheless, the VSV RdRp elongated the transcripts of 18-21 nt, but not transcripts of 8-12 nt (abortive transcripts), to full-length LeRNA (47 nt) during the chase period in the presence of GTP and UTP (Figure 8C, lane 2), indicating that active elongation complexes were successfully formed during the pulse period. Using this system, we revealed that VPI A inhibits synthesis of LeRNA $1-18$ (Figure 8B, lanes 2 and 3), rather than its elongation to full-length LeRNA (Figure 8C, lanes 3 and 4), whereas the divalent metal ion chelator EDTA abolishes both the reactions (Figure 8B, lane 4; Figure 8C, lane 5). These results suggest that VPI A affects an early step(s) of LeRNA synthesis, such as transcription initiation and transition from initiation to processive elongation. Since a transcript of $\sim 12 \mathrm{nt}$ appeared to be accumulated in the presence of $1 \mu \mathrm{M}$ VPI A during the pulse period (Figure 8 , lane 2), VPI A was thought to affect an early phase of RNA chain elongation to some extent.

Finally, to analyze the effects of VPI A on terminal de novo initiation for LeRNA synthesis, we performed the first phosphodiester bond formation (AC synthesis) using the N-RNA or a 20-nt oligo-RNA with the Le promoter sequence (Le(-)20) as a template [28]. VPI A was found to inhibit AC synthesis with the VSV L and P proteins from either template (Figure 9A,B, lanes 3 and 4), indicating that the $\mathrm{N}$ protein is not a target of VPI A. VPIs B-H also inhibited the first phosphodiester bond formation (Figure S4), consistent with their inhibitory activities against VSV mRNA synthesis (Figure 1 and Table 1). In addition, VPI A was found to inhibit de novo transcription initiation catalyzed by the CHPV RdRp, as well (Figure S5). Although the VSV L protein alone showed a $~ 75$-fold lower AC synthesis activity than in the presence of the P protein [28], it synthesized a detectable amount of AC (Figure 9C, lane 2). Using this system, we showed that VPI A inhibits AC synthesis with the VSV L protein alone by 85 and $100 \%$ at concentrations of 1 and $10 \mu \mathrm{M}$, respectively (Figure $9 \mathrm{C}$, lanes 3 and 4). In contrast, VPI A slightly reduced the capping activity of the PRNTase domain in the VSV L protein even at $10 \mu \mathrm{M}$ (Figure 9D, lane 4). Taken together, these results suggest that VPI A blocks transcription initiation, rather than elongation, by binding to the RdRp domain or its vicinity in the VSV L protein.
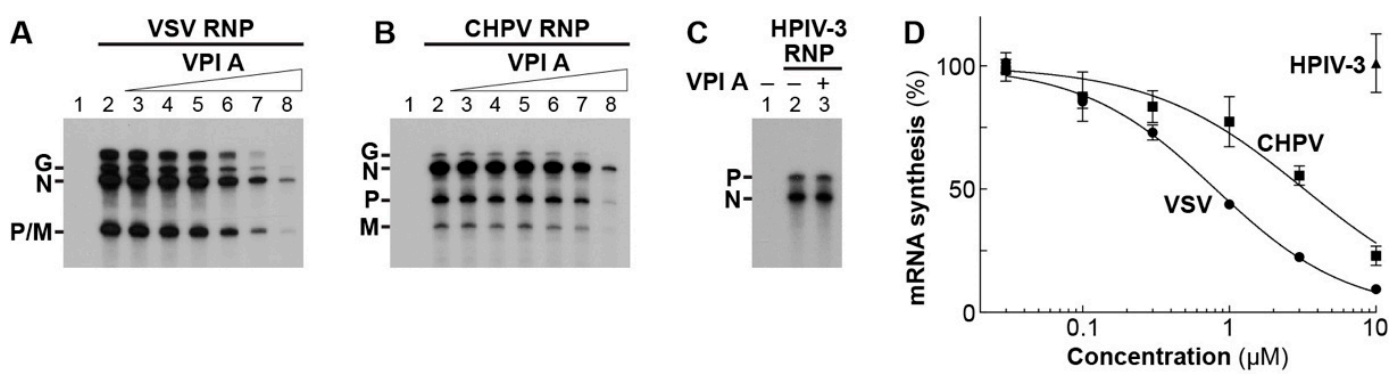

Figure 6. VPIs A and B inhibit mRNA synthesis of VSV and CHPV in vitro. In vitro mRNA synthesis was carried out with VSV (A), CHPV (B), or HPIV-3 (C) RNP in the presence or absence of VPI A (A and B, lanes 3-8, 0.03, 0.1, 0.3, 1, 3, $10 \mu \mathrm{M} ; \mathrm{C}$, lane 3, $10 \mu \mathrm{M}$ ). Deadenylated mRNAs were analyzed by $5 \%$ urea-PAGE followed by autoradiography. In (D), the graph shows relative activities for mRNA synthesis reactions, where radioactivities of transcripts synthesized without and with RNP (A-C, lanes 1 and 2, no drug) were set to 0 and 100\%, respectively. Symbols and error bars represent the means and standard deviations, respectively, of three independent experiments. 
A

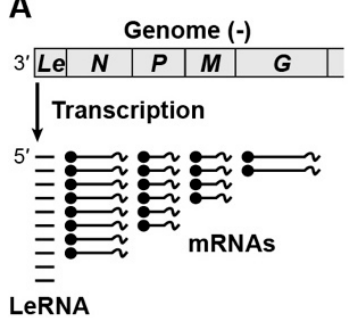

B LeRNA synthesis

$$
\text { RNP }
$$

VPI $A(\mu M)-\frac{110}{-11}$
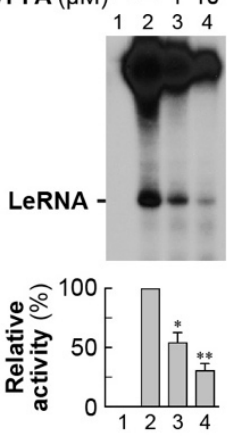

C mRNA synthesis RNP $-110$
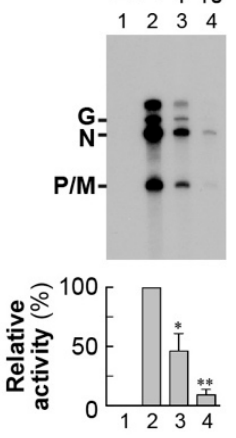

Figure 7. VPI A inhibits VSV LeRNA synthesis. As illustrated in (A), the VSV RdRp sequentially transcribes the genome in the N-RNA complex into the leader RNA (LeRNA) and 5'-capped and $3^{\prime}$-polyadenylated mRNAs. In vitro transcription was performed with VSV RNP in the presence or absence of 1 or $10 \mu \mathrm{M}$ VPI A. LeRNA and deadenylated mRNAs were analyzed by $20 \%$ (B) or $5 \%$ (C) urea-PAGE followed by autoradiography. The graphs show relative RNA synthesis activities, where radioactivities of each product synthesized without and with RNP (B and C, lanes 1 and 2, no drug) were set to 0 and $100 \%$, respectively. Statistical significance was determined by one-way ANOVA $\left({ }^{*}, p<0.05 ;{ }^{* *}, p<0.01\right.$; compared to control (column 2)).
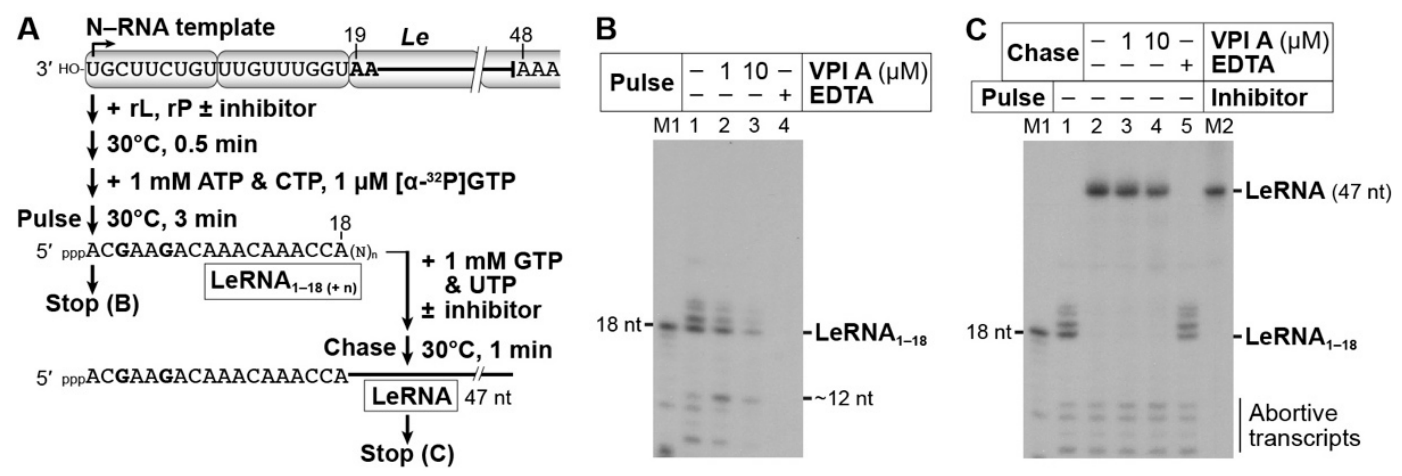

Figure 8. VPI A inhibits an early step of VSV LeRNA synthesis. The experimental design for pulse-chase transcription is schematically represented in (A). Partial RNA sequences of the $3^{\prime}$-terminal VSV genome and $5^{\prime}$-terminal LeRNA are shown. The recombinant VSV L and P proteins was premixed with the $\mathrm{N}-$ RNA template in the presence or absence of VPI A $(1$ or $10 \mu \mathrm{M})$ or EDTA $(25 \mathrm{mM})$. After adding ATP, CTP, and $\left[\alpha-{ }^{32} \mathrm{P}\right]$ GTP to the reactions, ${ }^{32}$ P-labeled LeRNA with residues 1-18 $\left(\right.$ LeRNA $\left._{1-18}\right)$ was synthesized for $3 \mathrm{~min}$ (pulse). The reactions were stopped (B) or proceeded to further RNA chain elongation with excess concentrations of GTP and UTP in the presence or absence of VPI A ( 1 or $10 \mu \mathrm{M})$ or EDTA $(25 \mathrm{mM})(\mathrm{C}$, chase). Transcripts were analyzed by $20 \%$ urea-PAGE followed by autoradiography. M1 and M2 lanes indicate ${ }^{32} \mathrm{P}$-labeled LeRNA ${ }_{1-18}$ and LeRNA synthesized by T7 RNA polymerase and VSV RNP, respectively. 

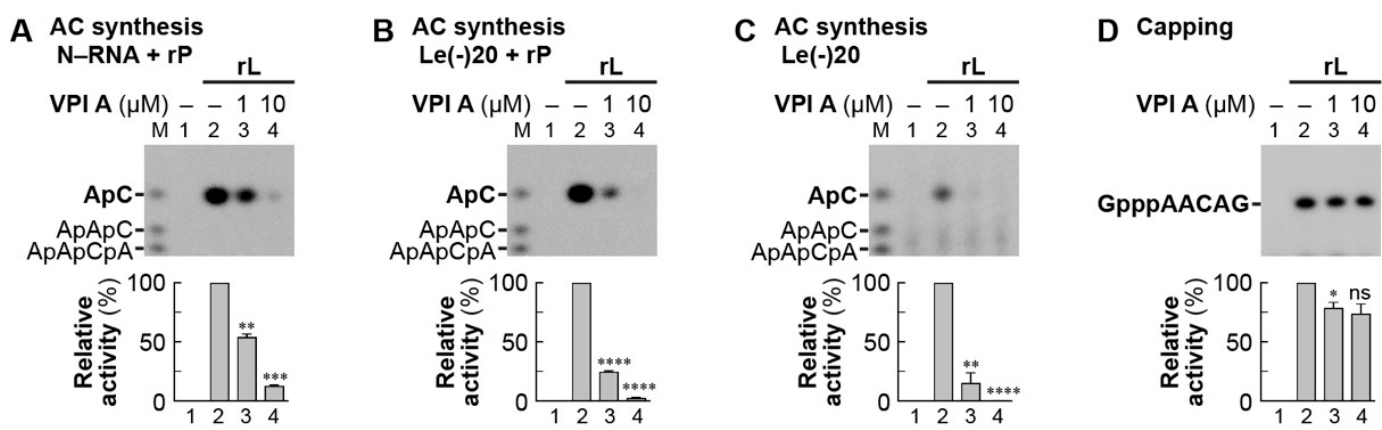

Figure 9. VPI A inhibits terminal de novo initiation of LeRNA synthesis with the VSV L protein. In vitro AC synthesis (first phosphodiester bond formation) by the recombinant VSV L protein was performed with $(\mathbf{A}, \mathbf{B})$ or without $(\mathbf{C})$ the P protein in the presence or absence of VPI A (1 or $10 \mu \mathrm{M})$. The N-RNA (A) or Le(-)20 oligo RNA (B,C) was used as a template. Calf intestine alkaline phosphatase-resistant RNA products were analyzed by $20 \%$ urea-PAGE followed by autoradiography. Lane 1 indicates no L protein. M lane shows $5^{\prime}$-hydroxyl oligo-RNAs with the indicated sequences. In (D), in vitro oligo-RNA capping by the recombinant VSV L protein was carried out with $\left[\alpha-{ }^{32} \mathrm{P}\right]$ GDP and pppAACAG in the presence or absence of VPI A ( 1 or $10 \mu \mathrm{M})$. The graphs show relative activities of AC synthesis (A-C) and oligo-RNA capping (D), where radioactivities of each product synthesized without and with the L protein (lanes 1 and 2, no drug) were set to 0 and 100\%, respectively. Statistical significance was

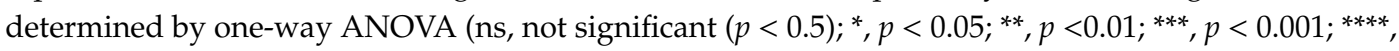
$p<0.0001$; compared to control (column 2)).

\section{Discussion}

In this study, we identified structurally related anti-VSV compounds, named vesiculopolins (VPIs), as VSV RdRp inhibitors, in which VPI A with a 4-methoxy-3-(1H-pyrazol-1-ylmethyl)phenyl group at position 4 is the most potent compound (Table 1, Figures 1-4). The aromatic groups at position 4 of VPIs largely affect their inhibitory activities against in vitro RNA synthesis as well as VSV-induced CPEs. It can be speculated that the common structure (7-hydroxy-6-methyl-3,4-dihydroquinolin-2(1H)-one) of VPIs is critical for binding to the L protein in the vicinity of its RdRp active site, whereas the distinct aromatic groups interfere with the functions of the RdRp domain differently possibly via steric hindrance. One unique observation was that VPI F with a 5-(1H-pyrazol-3-yl)-2-furyl group exhibits a weak inhibitory activity against terminal de novo initiation with the VSV RdRp (Supplementary Data, Figure S4), but induces the production of the unknown transcripts of 2-3 kilo nt in length (Figure 1C). Identification of the unknown transcripts will help understand the effects of VPI F on transcription. If these transcripts are generated by read-through of transcriptional stop-start signals on the genome, it would be interesting to elucidate the mechanism of the stop-start transcription using VPI F as a molecular probe. Structure-activity relationship studies are definitely necessary to define the unique inhibitory modes of VPIs, as well as to design more potent anti-VSV drugs using VPIs as lead compounds.

VPI A showed a weak anti-CHPV activity (Figure 5, Table 2) and, to a significantly lesser extent, anti-RABV activity when compared with its anti-VSV activity (Supplementary Data, Figure S2 and Table S1). The VSV L protein shares $60 \%$ and $36 \%$ amino acid sequence identity with the CHPV and RABV L proteins, respectively, suggesting that amino acid sequence differences within VPI A-binding sites among the L proteins may affect its affinities for the respective proteins. Although VPI A and other related compounds may have the potential to serve as lead compounds to develop antiviral drugs against CHPV and RABV, these compounds should be differently modified to fit the respective L proteins.

We demonstrated that VPI A inhibits terminal de novo initiation, rather than elongation, for VSV LeRNA synthesis (Figures 8 and 9). Therefore, once the VSV L protein forms an elongation complex, VPI A is no longer able to block RNA chain elongation. Similarly, benzimidazole-based non-nucleoside hepatitis $C$ virus RdRp inhibitors, which interact with the RdRp thumb subdomain, allosterically 
inhibit de novo initiation, but not processive elongation [54-56]. We have recently discovered that terminal de novo initiation at the $3^{\prime}$-end of the VSV genome requires a highly conserved tryptophan residue on the priming-capping loop [28], which is extended from the PRNTase domain into the $\mathrm{RdRp}$ active site cavity of the L protein. VPI A may interfere with an initiation-specific event, such as the initiation complex assembly on the 3'-terminal Le promoter of the genomic RNA and following first phosphodiester bond formation mediated by the priming-capping loop. LeRNA synthesis is a prerequisite for mRNA synthesis from the internal genes by stop-start transcription in vitro [53]. Thus, it can be assumed that inhibition of mRNA synthesis by VPI A is a secondary effect of inhibition of LeRNA synthesis (Figures 6 and 7), although we cannot rule out a direct effect of VPI A on internal de novo initiation for mRNA synthesis. In infected cells, VPI A may also abolish genome replication in the step of terminal de novo initiation. Further studies are currently underway to elucidate a type of RdRp inhibition by VPI A and to map its binding site in the VSV L protein.

Oncolytic virotherapy is an emerging approach to kill cancer cells with replication competent viruses. T-VEC, a genetically modified herpes simplex virus (HSV), has recently been approved by the U.S. Food and Drug Administration for the treatment of advanced melanoma (reviewed in [57]). One of the advantages of HSV based oncolytic viruses is the availability of anti-HSV drugs, such as acyclovir, that can render them harmless to patients when unanticipated dissemination of infection occurs. Similarly, anti-VSV drugs would enable control of VSV infection in patients, and thereby add further safety to the VSV therapy. Recently, Maraba vesiculovirus (MARAV), a cousin of VSV, has been proven to be a potent oncolytic virus in various preclinical cancer models (reviewed in [58]). Since the VSV and MARAV L proteins share $78 \%$ amino acid sequence identity, it would be interesting to investigate antiviral activities of VPIs against MARAV. These compounds are expected to serve as antidotes against these potent oncolytic vesiculoviruses. Further studies are needed to evaluate the effectiveness and safety of VPIs as anti-vesiculoviral agents in vivo using animal models.

In conclusion, we identified a new class of anti-VSV compounds by performing screening of small molecules. VPI A was found to inhibit the RNA synthesis activity of the L protein in the step of terminal de novo initiation. These compounds may be useful for developing drugs against vesiculoviruses, such as VSV, MARAV, and CHPV, and, by extension, other pathogenic human rhabdoviruses, such as RABV and Bas-Congo virus (associated with acute hemorrhagic fever [59]) as lead compounds. These compounds may also serve as molecular probes to elucidate the mechanisms of rhabdoviral RNA synthesis.

Supplementary Materials: The following are available online at http://www.mdpi.com/1999-4915/11/9/856/s1, Figure S1: VPI A inhibits VSV infection at an early post-entry step. Figure S2: Anti-RABV activities of VPIs A and B in NA cells., Figure S3: Anti-HPIV-3 activities of VPI A, VPI B, and ribavirin in HeLa cells., Figure S4. VPIs inhibit terminal de novo initiation of VSV RNA synthesis. Figure S5. VPI A inhibits terminal de novo initiation of CHPV RNA synthesis. Table S1: Anti-RABV activities of VPIs A and B, Table S2: Anti-HPIV-3 activities of VPI A, VPI B, and ribavirin.

Author Contributions: Conceptualization, T.O.; methodology, T.O., D.J.A., N.I. and M.S.; validation, M.O., T.O., Y.F., D.J.A., N.I. and M.S.; formal analysis, M.O., T.O., D.J.A., K.O., and N.I.; investigation, M.O., T.O., Y.F., D.J.A., K.O. and N.I.; writing — original draft preparation, M.O. and T.O.; writing—review and editing, T.O., M.O., Y.F., D.J.A., N.I. and M.S.; visualization, M.O. and T.O.; supervision, T.O., D.J.A., N.I., and M.S.; project administration, T.O.; funding acquisition, T.O.

Funding: This work was supported by funding from STERIS Corporation and Case Western Reserve University and grants from the National Institutes of Health (AI093569 and AI146172) to T.O.

Acknowledgments: The authors thank Amiya K. Banerjee (Cleveland Clinic) and John K. Rose (Yale University) for their generous gifts of the materials.

Conflicts of Interest: The authors declare no conflict of interest. The funders had no role in the design of the study; in the collection, analyses, or interpretation of data; in the writing of the manuscript, or in the decision to publish the results. 


\section{References}

1. Stojdl, D.F.; Lichty, B.; Knowles, S.; Marius, R.; Atkins, H.; Sonenberg, N.; Bell, J.C. Exploiting tumor-specific defects in the interferon pathway with a previously unknown oncolytic virus. Nat. Med. 2000, 6, 821-825. [CrossRef] [PubMed]

2. Stojdl, D.F.; Lichty, B.D.; tenOever, B.R.; Paterson, J.M.; Power, A.T.; Knowles, S.; Marius, R.; Reynard, J.; Poliquin, L.; Atkins, H.; et al. VSV strains with defects in their ability to shutdown innate immunity are potent systemic anti-cancer agents. Cancer Cell 2003, 4, 263-275. [CrossRef]

3. Lichty, B.D.; Power, A.T.; Stojdl, D.F.; Bell, J.C. Vesicular stomatitis virus: re-inventing the bullet. Trends Mol. Med. 2004, 10, 210-216. [CrossRef] [PubMed]

4. Hastie, E.; Grdzelishvili, V.Z. Vesicular stomatitis virus as a flexible platform for oncolytic virotherapy against cancer. J. Gen. Virol. 2012, 93, 2529-2545. [CrossRef] [PubMed]

5. Bourgeois-Daigneault, M.C.; Roy, D.G.; Falls, T.; Twumasi-Boateng, K.; St-Germain, L.E.; Marguerie, M.; Garcia, V.; Selman, M.; Jennings, V.A.; Pettigrew, J.; et al. Oncolytic vesicular stomatitis virus expressing interferon-gamma has enhanced therapeutic activity. Mol. Ther. Oncolytics 2016, 3, 16001. [CrossRef] [PubMed]

6. Felt, S.A.; Grdzelishvili, V.Z. Recent advances in vesicular stomatitis virus-based oncolytic virotherapy: A 5-year update. J. Gen. Virol. 2017, 98, 2895-2911. [CrossRef] [PubMed]

7. Mire, C.E.; Matassov, D.; Geisbert, J.B.; Latham, T.E.; Agans, K.N.; Xu, R.; Ota-Setlik, A.; Egan, M.A.; Fenton, K.A.; Clarke, D.K.; et al. Single-dose attenuated Vesiculovax vaccines protect primates against Ebola Makona virus. Nature 2015, 520, 688-691. [CrossRef]

8. Henao-Restrepo, A.M.; Camacho, A.; Longini, I.M.; Watson, C.H.; Edmunds, W.J.; Egger, M.; Carroll, M.W.; Dean, N.E.; Diatta, I.; Doumbia, M.; et al. Efficacy and effectiveness of an rVSV-vectored vaccine in preventing Ebola virus disease: final results from the Guinea ring vaccination, open-label, cluster-randomised trial (Ebola Ca Suffit!). Lancet 2017, 389, 505-518. [CrossRef]

9. Regules, J.A.; Beigel, J.H.; Paolino, K.M.; Voell, J.; Castellano, A.R.; Hu, Z.; Munoz, P.; Moon, J.E.; Ruck, R.C.; Bennett, J.W.; et al. A recombinant vesicular stomatitis virus Ebola vaccine. N. Engl. J. Med. 2017, 376, 330-341. [CrossRef]

10. Huttner, A.; Dayer, J.A.; Yerly, S.; Combescure, C.; Auderset, F.; Desmeules, J.; Eickmann, M.; Finckh, A.; Goncalves, A.R.; Hooper, J.W.; et al. The effect of dose on the safety and immunogenicity of the VSV Ebola candidate vaccine: a randomised double-blind, placebo-controlled phase 1/2 trial. Lancet Infect. Dis. 2015, 15, 1156-1166. [CrossRef]

11. Agnandji, S.T.; Huttner, A.; Zinser, M.E.; Njuguna, P.; Dahlke, C.; Fernandes, J.F.; Yerly, S.; Dayer, J.A.; Kraehling, V.; Kasonta, R.; et al. Phase 1 trials of rVSV Ebola vaccine in Africa and Europe. N. Engl. J. Med. 2016, 374, 1647-1660. [CrossRef] [PubMed]

12. Quiroz, E.; Moreno, N.; Peralta, P.H.; Tesh, R.B. A human case of encephalitis associated with vesicular stomatitis virus (Indiana serotype) infection. Am. J. Trop. Med. Hyg. 1988, 39, 312-314. [CrossRef] [PubMed]

13. van den Pol, A.N.; Dalton, K.P.; Rose, J.K. Relative neurotropism of a recombinant rhabdovirus expressing a green fluorescent envelope glycoprotein. J. Virol. 2002, 76, 1309-1327. [CrossRef] [PubMed]

14. Johnson, J.E.; Nasar, F.; Coleman, J.W.; Price, R.E.; Javadian, A.; Draper, K.; Lee, M.; Reilly, P.A.; Clarke, D.K.; Hendry, R.M.; et al. Neurovirulence properties of recombinant vesicular stomatitis virus vectors in non-human primates. Virology 2007, 360, 36-49. [CrossRef] [PubMed]

15. McWilliams, I.L.; Kielczewski, J.L.; Ireland, D.D.C.; Sykes, J.S.; Lewkowicz, A.P.; Konduru, K.; Xu, B.C.; Chan, C.C.; Caspi, R.R.; Manangeeswaran, M.; et al. Pseudovirus rVSVDeltaG-ZEBOV-GP infects neurons in retina and CNS, causing apoptosis and neurodegeneration in neonatal mice. Cell Rep. 2019, 26, 1718-1726 e4. [CrossRef] [PubMed]

16. Ogino, T.; Banerjee, A.K. An unconventional pathway of mRNA cap formation by vesiculoviruses. Virus Res. 2011, 162, 100-109. [CrossRef] [PubMed]

17. Ogino, T.; Green, T.J. RNA synthesis and capping by non-segmented negative strand RNA viral polymerases: lessons from a prototypic virus. Front. Microbiol. 2019, 10, 1490. [CrossRef] 
18. Abraham, G.; Rhodes, D.P.; Banerjee, A.K. The 5' terminal structure of the methylated mRNA synthesized in vitro by vesicular stomatitis virus. Cell 1975, 5, 51-58. [CrossRef]

19. Abraham, G.; Banerjee, A.K. Sequential transcription of the genes of vesicular stomatitis virus. Proc. Natl. Acad. Sci. USA 1976, 73, 1504-1508. [CrossRef]

20. Ball, L.A.; White, C.N. Order of transcription of genes of vesicular stomatitis virus. Proc. Natl. Acad. Sci. USA 1976, 73, 442-446. [CrossRef]

21. Testa, D.; Chanda, P.K.; Banerjee, A.K. Unique mode of transcription in vitro by Vesicular stomatitis virus. Cell 1980, 21, 267-275. [CrossRef]

22. Ogino, T.; Banerjee, A.K. Unconventional mechanism of mRNA capping by the RNA-dependent RNA polymerase of vesicular stomatitis virus. Mol. Cell 2007, 25, 85-97. [CrossRef] [PubMed]

23. Ogino, T.; Yadav, S.P.; Banerjee, A.K. Histidine-mediated RNA transfer to GDP for unique mRNA capping by vesicular stomatitis virus RNA polymerase. Proc. Natl. Acad. Sci. USA 2010, 107, 3463-3468. [CrossRef] [PubMed]

24. Ogino, T.; Banerjee, A.K. The HR motif in the RNA-dependent RNA polymerase L protein of Chandipura virus is required for unconventional mRNA-capping activity. J. Gen. Virol. 2010, 91, 1311-1314. [CrossRef] [PubMed]

25. Ogino, M.; Ito, N.; Sugiyama, M.; Ogino, T. The rabies virus L protein catalyzes mRNA capping with GDP polyribonucleotidyltransferase activity. Viruses 2016, 8, 144. [CrossRef] [PubMed]

26. Ogino, T. Capping of vesicular stomatitis virus pre-mRNA is required for accurate selection of transcription stop-start sites and virus propagation. Nucleic. Acids. Res. 2014, 42, 12112-12125. [CrossRef] [PubMed]

27. Neubauer, J.; Ogino, M.; Green, T.J.; Ogino, T. Signature motifs of GDP polyribonucleotidyltransferase, a non-segmented negative strand RNA viral mRNA capping enzyme, domain in the L protein are required for covalent enzyme-pRNA intermediate formation. Nucleic. Acids. Res. 2016, 44, 330-341. [CrossRef]

28. Ogino, M.; Gupta, N.; Green, T.J.; Ogino, T. A dual-functional priming-capping loop of rhabdoviral RNA polymerases directs terminal de novo initiation and capping intermediate formation. Nucleic Acids Res. 2019, 47, 299-309. [CrossRef]

29. Ogino, T.; Green, T.J. Transcriptional control and mRNA capping by the GDP polyribonucleotidyltransferase domain of the rabies virus large protein. Viruses 2019, 11, 504. [CrossRef]

30. Grdzelishvili, V.Z.; Smallwood, S.; Tower, D.; Hall, R.L.; Hunt, D.M.; Moyer, S.A. A single amino acid change in the L-polymerase protein of vesicular stomatitis virus completely abolishes viral mRNA cap methylation. J. Virol. 2005, 79, 7327-7337. [CrossRef]

31. Li, J.; Fontaine-Rodriguez, E.C.; Whelan, S.P. Amino acid residues within conserved domain VI of the vesicular stomatitis virus large polymerase protein essential for mRNA cap methyltransferase activity. J. Virol. 2005, 79, 13373-13384. [CrossRef] [PubMed]

32. Miyamoto, T.; Min, W.; Lillehoj, H.S. Lymphocyte proliferation response during Eimeria tenella infection assessed by a new, reliable, nonradioactive colorimetric assay. Avian Dis. 2002, 46, 10-16. [CrossRef]

33. Chadha, M.S.; Arankalle, V.A.; Jadi, R.S.; Joshi, M.V.; Thakare, J.P.; Mahadev, P.V.; Mishra, A.C. An outbreak of Chandipura virus encephalitis in the eastern districts of Gujarat state, India. Am. J. Trop. Med. Hyg. 2005, 73, 566-570. [CrossRef] [PubMed]

34. Tandale, B.V.; Tikute, S.S.; Arankalle, V.A.; Sathe, P.S.; Joshi, M.V.; Ranadive, S.N.; Kanojia, P.C.; Eshwarachary, D.; Kumarswamy, M.; Mishra, A.C. Chandipura virus: a major cause of acute encephalitis in children in North Telangana, Andhra Pradesh, India. J. Med. Virol. 2008, 80, 118-124. [CrossRef] [PubMed]

35. Schnell, M.J.; Buonocore, L.; Whitt, M.A.; Rose, J.K. The minimal conserved transcription stop-start signal promotes stable expression of a foreign gene in vesicular stomatitis virus. J. Virol. 1996, 70, 2318-2323.

36. Lawson, N.D.; Stillman, E.A.; Whitt, M.A.; Rose, J.K. Recombinant vesicular stomatitis viruses from DNA. Proc. Natl. Acad. Sci. USA 1995, 92, 4477-4481. [CrossRef]

37. Obuchi, M.; Fernandez, M.; Barber, G.N. Development of recombinant vesicular stomatitis viruses that exploit defects in host defense to augment specific oncolytic activity. J. Virol. 2003, 77, 8843-8856. [CrossRef]

38. Naik, S.; Nace, R.; Federspiel, M.J.; Barber, G.N.; Peng, K.W.; Russell, S.J. Curative one-shot systemic virotherapy in murine myeloma. Leukemia 2012, 26, 1870-1878. [CrossRef] 
39. Tober, R.; Banki, Z.; Egerer, L.; Muik, A.; Behmuller, S.; Kreppel, F.; Greczmiel, U.; Oxenius, A.; von Laer, D.; Kimpel, J. VSV-GP: A potent viral vaccine vector that boosts the immune response upon repeated applications. J. Virol. 2014, 88, 4897-4907. [CrossRef]

40. Garbutt, M.; Liebscher, R.; Wahl-Jensen, V.; Jones, S.; Moller, P.; Wagner, R.; Volchkov, V.; Klenk, H.D.; Feldmann, H.; Stroher, U. Properties of replication-competent vesicular stomatitis virus vectors expressing glycoproteins of filoviruses and arenaviruses. J. Virol. 2004, 78, 5458-5465. [CrossRef]

41. Jones, S.M.; Feldmann, H.; Stroher, U.; Geisbert, J.B.; Fernando, L.; Grolla, A.; Klenk, H.D.; Sullivan, N.J.; Volchkov, V.E.; Fritz, E.A.; et al. Live attenuated recombinant vaccine protects nonhuman primates against Ebola and Marburg viruses. Nat. Med. 2005, 11, 786-790. [CrossRef] [PubMed]

42. Cooper, D.; Wright, K.J.; Calderon, P.C.; Guo, M.; Nasar, F.; Johnson, J.E.; Coleman, J.W.; Lee, M.; Kotash, C.; Yurgelonis, I.; et al. Attenuation of recombinant vesicular stomatitis virus-human immunodeficiency virus type 1 vaccine vectors by gene translocations and g gene truncation reduces neurovirulence and enhances immunogenicity in mice. J. Virol. 2008, 82, 207-219. [CrossRef] [PubMed]

43. Yamaoka, S.; Ito, N.; Ohka, S.; Kaneda, S.; Nakamura, H.; Agari, T.; Masatani, T.; Nakagawa, K.; Okada, K.; Okadera, K.; et al. Involvement of the rabies virus phosphoprotein gene in neuroinvasiveness. J. Virol. 2013, 87, 12327-12338. [CrossRef] [PubMed]

44. Zhang, J.H.; Chung, T.D.; Oldenburg, K.R. A simple statistical parameter for use in evaluation and validation of high throughput screening sssays. J. Biomol. Screen. 1999, 4, 67-73. [CrossRef] [PubMed]

45. Walters, W.P.; Namchuk, M. Designing screens: How to make your hits a hit. Nat. Rev. Drug Discov. 2003, 2, 259-266. [CrossRef] [PubMed]

46. Crowley, L.C.; Marfell, B.J.; Waterhouse, N.J. Analyzing cell death by nuclear staining with Hoechst 33342. Cold Spring Harb. Protoc. 2016, 2016, 778-781. [CrossRef] [PubMed]

47. Ogino, T. In vitro capping and transcription of rhabdoviruses. Methods 2013, 59, 188-198. [CrossRef] [PubMed]

48. Obijeski, J.F.; Marchenko, A.T.; Bishop, D.H.; Cann, B.W.; Murphy, F.A. Comparative electrophoretic analysis of the virus proteins of four rhabdoviruses. J. Gen. Virol. 1974, 22, 21-33. [CrossRef]

49. Ogino, T.; Fukuda, H.; Imajoh-Ohmi, S.; Kohara, M.; Nomoto, A. Membrane binding properties and terminal residues of the mature hepatitis C virus capsid protein in insect cells. J. Virol. 2004, 78, 11766-11777. [CrossRef]

50. Ogino, M.; Ogino, T. 5'-Phospho-RNA acceptor specificity of GDP polyribonucleotidyltransferase of vesicular stomatitis virus in mRNA capping. J. Virol. 2017, 91, e02322-02316. [CrossRef]

51. Fensterl, V.; Wetzel, J.L.; Ramachandran, S.; Ogino, T.; Stohlman, S.A.; Bergmann, C.C.; Diamond, M.S.; Virgin, H.W.; Sen, G.C. Interferon-induced Ifit2/ISG54 protects mice from lethal VSV neuropathogenesis. PLoS Pathog. 2012, 8, e1002712. [CrossRef] [PubMed]

52. Shah, N.R.; Sunderland, A.; Grdzelishvili, V.Z. Cell type mediated resistance of vesicular stomatitis virus and Sendai virus to ribavirin. PLoS ONE 2010, 5, e11265. [CrossRef] [PubMed]

53. Emerson, S.U. Reconstitution studies detect a single polymerase entry site on the vesicular stomatitis virus genome. Cell 1982, 31, 635-642. [CrossRef]

54. Tomei, L.; Altamura, S.; Bartholomew, L.; Biroccio, A.; Ceccacci, A.; Pacini, L.; Narjes, F.; Gennari, N.; Bisbocci, M.; Incitti, I.; et al. Mechanism of action and antiviral activity of benzimidazole-based allosteric inhibitors of the hepatitis C virus RNA-dependent RNA polymerase. J. Virol. 2003, 77, 13225-13231. [CrossRef] [PubMed]

55. McKercher, G.; Beaulieu, P.L.; Lamarre, D.; LaPlante, S.; Lefebvre, S.; Pellerin, C.; Thauvette, L.; Kukolj, G. Specific inhibitors of HCV polymerase identified using an NS5B with lower affinity for template/primer substrate. Nucleic Acids Res. 2004, 32, 422-431. [CrossRef] [PubMed]

56. Rigat, K.L.; Lu, H.; Wang, Y.K.; Argyrou, A.; Fanslau, C.; Beno, B.; Wang, Y.; Marcinkeviciene, J.; Ding, M.; Gentles, R.G.; et al. Mechanism of inhibition for BMS-791325, a novel non-nucleoside inhibitor of hepatitis C virus NS5B polymerase. J. Biol. Chem. 2014, 289, 33456-33468. [CrossRef]

57. Conry, R.M.; Westbrook, B.; McKee, S.; Norwood, T.G. Talimogene laherparepvec: First in class oncolytic virotherapy. Hum. Vaccin. Immunother. 2018, 14, 839-846. [CrossRef] 
58. Pol, J.G.; Atherton, M.J.; Bridle, B.W.; Stephenson, K.B.; Le Boeuf, F.; Hummel, J.L.; Martin, C.G.; Pomoransky, J.; Breitbach, C.J.; Diallo, J.S.; et al. Development and applications of oncolytic Maraba virus vaccines. Oncolytic Virother 2018, 7, 117-128. [CrossRef]

59. Grard, G.; Fair, J.N.; Lee, D.; Slikas, E.; Steffen, I.; Muyembe, J.J.; Sittler, T.; Veeraraghavan, N.; Ruby, J.G.; Wang, C.; et al. A novel rhabdovirus associated with acute hemorrhagic fever in central Africa. PLoS Pathog. 2012, 8, e1002924. [CrossRef]

(C) 2019 by the authors. Licensee MDPI, Basel, Switzerland. This article is an open access article distributed under the terms and conditions of the Creative Commons Attribution (CC BY) license (http://creativecommons.org/licenses/by/4.0/). 